\title{
STRATEGI CART SORT UNTUK PENINGKATKAN KEAKTIFAN PEMBELAJARAN PKn SISWA SMP
}

\author{
Oleh: \\ Ahmad Nasir Ari Bowo*, Dewi Mutmayana* \\ Universitas Cokroaminoto Yogyakarta
}

\begin{abstract}
Abstrak
Tujuan umum penelitian ini adalah untuk meningkatkan keaktifan siswa dalam mata pelajaran PKn Materi HAM pada siswa kelas VII SMP Negeri 4 Satu Atap Gabus melalui penerapan strategi pembelajaran Card Sort. Subjek pelaksanaan tindakan adalah siswa kelas VII SMP Negari 4 Satu Atap yang berjumlah 36 siswa. Data penelitian ini dikumpulkan melalui informen atau nara sumber, tempat dan peristiwa berlangsungnya aktifitas pembelajaran dan dokumen atau arsip.Teknik pengumpulan data dengan menggunakan metode observasi. Prosedur dalam penelitian ini terdapat empat tahap yaitu perencanaan, pelaksanan, pengamatan dan refleksi. Hasil penelitian ini menunjukkan bahwa tingkat keaktifan siswa pada materi HAM di kelas VII SMP Negeri Satu Atap Gabus, yaitu dari siswa yang aktif bertanya, berpendapat dan menjawab pertanyaan sebanyak $5(13,90 \%)$ siswa. Setelah dilakukan tindakan yang disepakati yaitu dengan menerapkan strategi Card Sort pada pembelajaran diperoleh hasil yaitu siklus I meningkat menjadi $20(55,60 \%)$ siswa. Setelah dilakukan tindakan yang direvisi pada siklus II diperoleh meningkat menjadi $29(80,60 \%)$ siswa. Hasil penelitian ini sudah memenuhi idikator kinerja.
\end{abstract}

Kata Kunci: Strategi pembelajaran, Siklus, tindakan.

\section{Pendahuluan}

Hak asasi manusia merupakan mata pelajaran yang dipelajari di SMP kelas VII semester genap. Keaktifan siswa tentang materi ini sangat kurang. Hal tersebut di karenakan keaktifan siswa pada waktu mengikuti materi ini, baik dalam bertanya dan berpendapat dan menjawab pertanyaan sangat kurang. Jumlah siswa dalam satu kelas adalah 36 siswa. Dari jumlah siswa tersebut hanya 5 orang yang aktif dalam mengikuti materi HAM baik yang bertanya dan berpendapat serta menjawab pertanyaan. Hal tersebut diperparah oleh kurangnya guru menggunakan variasi strategi mengajar. Untuk mengatasi permasalahan tersebut guru telah mencoba berbagai metode. Metode yang telah dilaksanakan guru selama ini diantaranya adalah metode ceramah diselingi tanya jawab, dan diskusi, disini siswa hanya men-dengarkan penjelasan guru ada yang memperhatikan dan ada yang melakukan aktivitas lain misalnya: ada yang ngobrol sama teman sebangkunya, mencoret-coret buku, bahkan ada yang tidur. Berdasarkan kenyataan 
tersebut maka dapat dilihat adanya kesenjangan, antara apa yang terjadi dengan apa yang diharapkan. Rendahnya keaktifan dalam mempelajari materi HAM secara tidak langsung mempengaruhi tujuan materi pembelajaran yang hendak dicapai. Oleh karena itu, perlu dilakukan tindakan kelas lain yang diharapkan mampu meningkatkan keaktifan siswa materi HAM. Solusi alternatif yang ditawarkan adalah pemberian nilai tambahan pada siswa yang dapat menjawab pertanyaan dan bertanya. Harapan guru dengan solusi itu siswa akan termotivasi untuk aktif di kelas, tetapi strategi ini pun hasilnya masih gagal. Berdasarkan latar belakang masalah yang telah dikemukakan di atas maka dipandang cukup penting untuk mengadakan penelitian tindakan kelas tentang "Penerapan Srategi Pembelajaran Card Sort sebagai Upaya Meningkatkan Keaktifan dalam Proses Pembelajaran PKn Materi HAM Pada Siswa Kelas VII SMP Negeri 4 Satu Atap Gabus.

Upaya untuk meningkatkan keaktifan siswa materi HAM pada dasarnya dapat dipengaruhi oleh banyak faktor yang saling berkaitan baik dari dalam diri siswa (internal) maupun dari luar siswa (eksternal). Beberapa masalah yang berkaitan dengan upaya untuk meningkatkan keaktifan materi tentang HAM antara lain: kondisi fisik siswa, cara mengajar guru, suasana kelas, media yang digunakan dalam pembelajaran, penguasaan materi siswa, perhatian siswa. Dalam konteks ini tentu saja masih banyak lagi masalah yang dapat dikemukakan yang berkaitan dengan upaya meningkatkan keaktifan materi tentang HAM (Hak asasi manusia). Berdasarkan latar belakang masalah dan identifikasi masalah di atas, maka dipandang cukup penting untuk mengadakan penelitian tindakan kelas tentang "Penerapan Srategi Pembelajaran Card Sort Sebagai Upaya Meningkatkan Keaktifan dalam Proses Pembelajaran PKn Materi HAM Pada Siswa Kelas VII SMP Negeri 4 Satu Atap Gabus.

Permasalahan yang berkaitan dengan judul sangat luas sehingga tidak mungkin permasalahan yang ada dapat terjangkau dan terselesaikan semua. Oleh karena itu, perlu adanya pembatasan dan pemfokusan masalah sehingga masalah yang diteliti lebih jelas dan kesalahpahaman dapat dihindari. Dalam penelitian tindakan kelas ini variabel penelitian sebanyak dua jenis. Variabel penerapan strategi pembelajaran Card Sort sebagai variabel terikat. Adapun yang menjadi bagian dari variabel tersebut adalah: a) siswa SMP Negeri 4 Satu Atap Gabus, b) kelas VII semester genap, c) mata pelajaran Pendidikan Kewarganegaraan materi HAM, d) variabel meningkatkan keaktivan siswa dalam proses pembelajaran sebagai variabel bebas. 


\section{Kajian Teoritis}

Pengertian Card Sort. Menurut Zaini, dkk (2002:53) Card Sort artinya "Sortir kartu", yang dimaksud sortir kartu adalah mencocokan/menyamakan antara kartu yang sudah di tentukan dan siswa mencari pasangannya masing- masing. Untuk menentukan kartu yang sama maka siswa harus bekerja dan mencari kartu yang sama dengan temanya yang lain sampai ketemu. strategi pembelajaran Card Sort yaitu cara-cara yng dipilih guru dalam pembelajaran kelompok, dimana hasil kelompok tersebut dalam bentuk mencocokan materi yang sama dengan judul yang sudah ditentukan, setelah ketemu dengan pasangannya kelompok tersebut mempresentasikan materi tersebut. Dengan demikian, sortir kartu akan menimbulkan keaktifan siswa dengan mencari pasangannya.

Langkah-langkah penerapan strategi pembelajaran Card sort. Menurut pendapat Zaini, dkk (2002:53-54). Langkah-langkah metode Card Sort adalah sebagai berikut:

1) Setiap siswa/mahasiswa diberi potongan yang berisi informasi atau cotoh yang tercakup dalam satu atau lebih kategori. Berikut beberapa contoh: karakteristik hadits sohih, nouns, verb, advebs, and proposition, ajaran Mu'tazilah, dll.

2) Mintalah siswa/mahasiswa untuk bergerak dan berkeliling didalam kelas untuk menemukan kartu dengan kategori yang sama. (Anda dapat meng-gunakan kategori tersebut sebelumnya atau membicarakan siswa/maha-siswa menemukannya sendiri).

3) Siswa/mahasiswa dengan kategori yang sama diminta mempresentasikan kategori masingmasing didepan kelas,

4) Seiring dengan presentasi dari tiap-tiap kategori tersebut, berikan poin-poin penting terkait materi pelajaran/perkuliahan.

Pengertian keaktifan siswa. Menurut Tim Penyusun Kamus Pusat Pembinaan dan Pengembangan Bahasa Depdikbud RI (1991:19) aktif artinya "giat" (bekerja, berusaha). Keaktifan diartikan sebagai "kegiatan atau kesibukan". Sementara itu menurut Tim Penyusun Kamus Pusat Pembinaan dan Peng-embangan Bahasa Depdikbud RI (1991:951) siswa diartikan sebagai "murid atau pelajar". Selanjutnya berdasarkan uraian tersebut dapat diambil kesimpulan keaktifan siswa adalah suatu kegiatan atau kesibukan belajar yang di lakukan siswa dalam menempuh pendidikan dari sekolah dasar sampai menengah dengan belajar yang giat.

Hasil penelitian tindakan kelas Fitriasari (2007: 84) membuktikan adanya peningkatan keaktifan belajar siswa dalam pembelajaran matematika dengan pendekatan pola latihan 
interaktif pola bahasa Geometri. Sementara itu Astuti (2007:92) membuktikan adanya peningkatan keaktifan siswa dalam merespon pelajaran matematika melalui pendekatan ketrampilan proses (PKP). Berdasarkan hasil penelitian tindakan di atas dapat disimpulkan bahwa keaktifan siswa sangat dipengaruhi oleh strategi pembelajaran aktif, dalam pene-litian ini strategi yang diterapkan adalah Card Sort. Oleh karena itu, sangat beralasan diadakan kajian mengenai penerapan strategi pembelajaran Card Sort sebagai upaya meningkatkan keaktifan dalam proses pembelajaran PKn pada siswa kelas VII SMP Negari Satu Atap Gabus.

Berdasarkan kajian teoritis sebagaimana telah dipaparkan di atas, maka dalam penelitian ini dipandang perlu mengajukan kerangka pemikiran sebagai berikut:

1. Penggunaan model pembelajaran Card Sort akan mengaktifkan siswa pada waktu mengikuti materi pelajaran HAM.

2. Penggunaan model pembelajaran Card Sort akan melibatkan siswa dalam proses pembelajaran secara aktif.

3. Adanya keterkaitan antara penggunaan model pembelajaran Card Sort dengan peningkatkan keaktifan siswa tentang materi HAM.

Bila digambarkan maka akan tampak sebagaimana gambar siklus berikut ini.

\begin{tabular}{|l|l|l|l|}
\hline $\begin{array}{l}\text { Keaktifan siswa } \\
\text { dalam proses } \\
\text { pembelajaran } \\
\text { rendah. }\end{array}$ & $\begin{array}{l}\text { Guru kurang } \\
\text { mengaktifkan } \\
\text { siswa pada waktu } \\
\text { mengikuti } \\
\text { pelajaran. }\end{array}$ \\
\cline { 2 - 3 }
\end{tabular}$\quad \longrightarrow$\begin{tabular}{l}
$\begin{array}{l}\text { Rendahnya } \\
\text { penguasaan materi } \\
\text { siswa pada waktu } \\
\text { mengikuti } \\
\text { pelajaran. }\end{array}$ \\
\hline
\end{tabular}

Gambar 1. Kerangka Pemikiran

Hipotesis yang diajukan dalam penelitian ini adalah: "Diduga dari Penerapan Srategi Pembelajaran Card Sort dapat Meningkatkan Keaktifan dalam Proses Pembelajaran PKn Materi HAM Pada Siswa Kelas VII SMP Negeri 4 Satu Atap Gabus. 


\section{Metode Penelitian}

Tempat penelitian ini adalah di SMP Negari 4 Satu Atap Gabus. Tahap-tahap pelaksanaan kegiatan sejak persiapan sampai dengan penulisan laporan penelitian secara keseluruhan dilakukan selama kurang lebih empat bulan, yaitu sejak bulan April sampai dengan bulan Juli 2012. Subjek dalam penelitian ini adalah guru PKn kelas VII dan Kepala sekolah SMP 4 Satu Atap Gabus sebagai subjek yang membantu dalam perencanaan dan pengumpulan data penelitian. Seluruh siswa kelas VII SMP 4 Satu Atap Gabus sebagai subjek penelitian yang menerima tindakan. Peneliti sebagai subjek yang bertugas merencanakan, mengumpulkan data, menganalisis data, dan membuat kesimpulan penelitian. Dalam penelitian ini informan yaitu yang memberikan keterangan dan data-data yang diperlukan diantaranya adalah:

1. Siswa kelas VII semester genap SMP Negeri 4 Satu Atap Gabus.

2. Guru mata pelajaran PKn kelas VII.

Teknik pengumpulan data dalam penelitian ini menggunakan observasi langsung. Menurut Nawawi (1992:74) "Observasi adalah pengamatan dan pencatatan secara sistematik terhadap unsur-unsur yang tampak dalam suatu gejala atau gejala-gejala pada obyek penelitian". Melalui observasi peneliti dapat mengetahui kegiatan siswa dalam mempersiapkan, memperhatikan dan menang-gapi penjelasan dari guru selama proses pembelajaran. Dalam penelitian ini metode observasi digunakan untuk mengamati keaktifan siswa kelas VII SMP Negeri 4 Satu Atap pada saat proses penerapan strategi pembelajaran Card Sort dalam materi HAM pada mata pelajaran PKn.

Ada beberapa teknik yang dapat digunakan untuk mengetahui validitas data (kestabilan data). Penelitian ini menggunakan dua macam triangulasi, yang pertama triangulasi sumber data yang berupa informasi sari guru dan siswa tentang tindakan yang diterapkan. Kedua triagulasi teknik atau metode pengum-pulan dari hasil observasi.

Adapun model dan penjelasan untuk masing-masing tahapan adalah sebagai berikut:

\section{Siklus I}

a. Perencanaan Tindakan, perencanaan tindakan ini mengacu pada hasil dialog awal yang telah diru-muskan sebagai fokus permasalahan. Selanjutnya disusun langkah persiapan tin-dakan pembelajaran yang terdiri: 
1) Identifikasi masalah. Peneliti merumuskan permasalahan siswa sebagai upaya untuk meningkat-kan pemahaman siswa khususnya pada mata pelajaran HAM. Tindakan yang diterapkan pada identifikasi masalah antara lain:

a) Penerapan strategi pengajaran yaitu strategi Card Sort.

b) Bagaimana menyikapi keaktifan siswa pada materi HAM siswa kelas VII SMP Negeri 4 Satu Atap Gabus ?

c) Bagaimana mengusahakan siswa untuk aktif dalam proses pembelajaran materiHAM?

2) Perencanaan solusi masalah.

b. Pelaksanaan Tindakan. tindakan dilaksanakan oleh peneliti dan guru sebagai mitra kolaborasi berdasarkan perencanaan yang telah dibuat sebelumnya. Perencanaan pengajaran bersifat fleksibel artinya selalu dapat di kondisikan atau dapat berubah sesuai kebutuhan pada saat pengajaran berlangsung.

c. Observasi dan Monitoring, observasi dan monitoring adalah upaya merekam segala peristiwa dan kegiatan yang terjadi selama tindakan itu berlangsung. Dalam penelitian ini, peneliti selain bertindak sebagai pelaksana tindakan juga sebagai observer. Observer mengamati segala kegiatan siswa di dalam kelas dan mencatatnya dalam pedoman observasi yang telah dibuat. Observasi dan monitoring dilaksanakan pada pelaksanaan tindakan.

d. Refleksi, dimaksudkan untuk mengkaji apa yang telah terjadi atau yang ti-dak terjadi, apa yang telah dihasilkan atau yang belum dihasilkan selama tindakan berlangsung. Hasil refleksi tersebut digunakan untuk menentukan langkah-langkah selanjutnya dalam upaya mencapai tujuan. Dengan kata lain, refleksi merupakan pengkajian terhadap keberhasilan atau kegagalan dalam pencapaian tujuan sementara. Refleksi dilakukan oleh peneliti dan guru yang berupa pengamatan untuk menelaah hasil tindakan yang telah dilakukan.

2. Siklus II

a. Perencanaan Tindakan, perencanaan tindakan ini mengacu pada hasil tindakan pertama yang telah dilaksanakan sebagai solusi pemecahan permasalahan. Selanjutnya disusun lang-kah persiapan tindakan pembelajaran pada siklus II sebagai berikut:

1) Identifikasi masalah, tindakan yang diterapkan pada identifikasi masalah didasarkan pada hasil tindakan siklus I antara lain:

a) Mengevaluasi kelemahan strategi Card Sort.

b) Menyikapi peningkatan pemahaman siswa pada materi HAM 
c) Mengidentifikasi peningkatan keaktifan siswa pada materi HAM.

2) Perencanaan solusi masalah. Solusi yang peneliti tawarkan untuk mengatasi permasalahan yang berkaitan dengan pemahaman siswa adalah penerapan strategi Card Sort divariasikan dengan metode lain, tindakan pembelajaran untuk meningkatkan keaktifan siswa yaitu memberi penugasan kepada siswa yang tidak terstruktur.

b. Pelaksanaan Tindakan, telaksanaan tindakan siklus II dilaksanakan pada pertemuan berikutnya setelah siklus I selesai dilaksanakan. Peneliti bertindak sebagai guru berdasarkan perencanaan yang telah dibuat sebelumnya.

c. Observasi dan Monitoring. Observasi dan monitoring dilaksanakan untuk melihat jalannya pelaksanaan tindakan yang didasarkan pada pelaksanaan siklus I. Semua proses jalannya pembelajaran dan peningkatan keaktifan siswa terhadap materi HAM serta didokumentasikan oleh peneliti.

d. Refleksi pada siklus II dilakukan setelah semua proses pembelajaran selesai dilaksanakan. Permasalahan-permasalahan yang ada dikaji dan dicarikan solusinya. Hasil refleksi digunakan untuk menentukan langkah-langkah selanjut-nya dalam upaya mencapai tujuan. Dalam siklus II sudah mencapai indikatior kinerja.

\section{Hasil Penelitian dan Pembahasan}

\section{Kondisi Awal Kelas VII SMP Negeri 4 Satu Atap Gabus}

HAM merupakan bagian materi pelajaran PKn di SMP kelas VII semester II. Berdasarkan pengalaman guru, jumlah siswa kelas VII yang aktif dalam bertanya dalam hal yang belum jelas, mengemukakan pendapat atau ide dan keaktifan siswa dalam menjawab pertanyaan berjumlah kurang lebih hanya $5(13,60 \%)$ dari keseluruhan siswa. Secara lebih rinci daftar keaktifan siswa kelas VII dapat dilihat pada tabel di bawah ini.

Tabel 2. Daftar keaktifan siswa kelas VII sebelum pelaksanaan strategi Card Sort.

\begin{tabular}{|c|l|c|}
\hline No & \multicolumn{1}{|c|}{ Keaktifan siswa } & Banyak (Prosentase) \\
\hline 1 & Keaktifan bertanya & 2 Siswa $(5,55 \%)$ \\
\hline 2 & Keaktifan dalam mengemukakan pendapat atau ide. & 1 Siswa $(2,77 \%)$ \\
\hline 3 & Keaktifan menjawab pertanyaan & 1 Siswa $(2,77 \%)$ \\
\hline \multicolumn{2}{r}{ Jumlah total } & 5 Siswa $(13,88 \%)$ \\
\hline
\end{tabular}

Sumber: Hasil wawancara dengan guru kelas VII 
Pemahaman siswa pada materi ini juga kurang maksimal. Hal tersebut dikarenakan keaktifan siswa pada waktu mengikuti materi ini, baik dalam bertanya, berpendapat dan menjawab pertanyaan sangat kurang. Jumlah siswa dalam satu kelas adalah 36 siswa, dari jumlah tersebut hanya 5 siswa yang aktif dalam mengikuti materi HAM baik yang bertanya, berpendapat maupun menjawab pertanyaan. Oleh karena itu, perlu diadakan langkah alternatif yang diharapkan mampu meningkatkan keaktifan siswa pada mata pelajaran HAM entah itu dalam bertanya tentang hal yang yang belum jelas, menjawab pertanyaan maupun mengemukakan pendapat atau ide pada materi HAM. Untuk itu peneliti mengajukan strategi pembelajaran Card Sort sebagai upaya meningkatkan keaktifan siswa. Alasan dipilihnya strategi pembelajaran Card Sort karena strategi ini memiliki beberapa kelebihan dibandingkan dengan strategi lainnya. Kelebihan strategi pembelajaran ini antara lain siswa akan lebih aktif dalam mengikuti pelajaran karena setiap siswa akan terlibat dalam mempresentasikan salah satu kategori yang berisi informasi yang mencakup materi yang sudah disampaikan. Dengan demikian keaktifan siswa dalam mengikuti pelajaran dapat meningkat.

\section{Evaluasi Upaya Meningkatkan Keaktifan dalam Proses Pembelajaraan Pada Materi HAM}

Pembahasan terhadap permasalahan penelitian maupun hipotesis tindakan berdasarkan analisis data kualitatif hasil penelitian dari kolaboratif antara peneliti dan praktisi pendidikan dan tanggapan guru PKn yang terlibat dalam kegiatan ini, serta profil kelas sebelum dan sesudah penelitian yang dibuat oleh peneliti yang melakukan tindakan kerja kolaborasi dimulai dari: (1) perencanaan tindakan, (2) pelaksanaan tindakan, (3) pengamatan tindakan, (4) refleksi hasilnya sebagai berikut, tentang proses pembelajaran dengan strategi Card Sort dan hasi penelitian yang dilakukan secara kolaboratif antara peneliti, guru kelas dan kepala sekolah menyatakan bahwa dalam proses pembelajaran pada materi HAM dengan menggunakan strategi Card Sort telah memberikan dorongan kepada guru untuk mengembangkan strategi pembelajaran baru yang inovatif dalam melakukan pembelajaran yang mengikut sertakan peserta didik, sehingga dalam proses pembelajaran tidak berpusat pada guru dan peserta didik juga bisa bersosialisasi dengan peserta didik yang lainya. Pembelajaran dengan menggunakan Strategi Card Sort ini meminta peserta didik aktif berinteraksi dengan sesama temannya, sehingga mereka lebih aktif dalam bertanya maupun berpendapat serta menjawab pertanyaan agar lebih mudah memahami materi dan terlibat langsung dalam proses pembelajaran. Berkaitan dengan keaktifan bertanya dan berpendapat serta menjawab pertanyaan pada materi HAM peserta didik, dengan adanya strategi 
Card Sort ini secara perlahan-lahan keaktifan bertanya dan berpendapat serta menjawab pertanyaan peserta didik dalam mengikuti pelajaran mengalami peningkatan disetiap tindakan kelas yang dilakukan oleh peneliti. Peserta didik menjadi semakin "mampu" dalam arti peserta didik semakin aktif dalam menyampaikan pertanyaan atau pendapat serta menjawab pertanyaan disetiap mengikuti pelajaran. Oleh karena itu maka siswa benar-benar memahami pengetahuan yang diberikan oleh guru sehingga keaktifan dalam materi ajar dapat maksimal. Strategi Card Sort dapat meningkatkan partisipasi dan keaktifan siswa dalam pembelajaran materi HAM, guru kelas VII melakukan pembenahan pelaksanaan tindakan pada saat proses belajar mengajar. Pembenahan tindakan tersebut adalah dengan mengaktifkan siswa. Keaktifan peserta didik dalam bertanya, sebelum penelitian hanya $5(13,90 \%)$ peserta didik yang berani bertanya dan berpendapat serta menjawab pertanyaan apabila mengalami kesulitan, kemudian peneliti menerapkan proses pembelajaran baru yaitu dengan menggunakan strategi Card Sort partisipasi peserta didik pada siklus I dalam mengajukan pertanyaan dan berpendapat serta menjawab pertanyaan meningkat menjadi $20(55,60 \%)$ peserta didik. Kemudian peneliti mengadakan revisi dan evaluasi lagi untuk mendapatkan hasil yang optimal dan akhirnya peneliti melaksanakan siklus II dan didapatkan hasil $29(80,60 \%)$ peserta didik yang berani dan mampu mengajukan pertanyaan dan berpendapat serta menjawab pertanyaan. Untuk mengaktifkan peserta didik juga di lakukan penambahan pembimbing atau pengawas yang berperan untuk membantu guru kelas dalam memberikan penjelasan dan motivasi kepada siswa agar siswa lebih aktif dalam proses pembelajaran. Melalui strategi Card Sort dapat terlihat bagaimana peningkatan keaktifan bertanya dan berpendapat serta menjawab pertanyaan peserta didik mulai dari sebelum penelitian hingga penelitian berakhir. Tingkat keaktifan siswa dalam bertanya dan berpendapat serta menjawab pertanyaan kelas VII SMP Negeri 4 Satu Atap Gabus, yaitu sebanyak 5 (13, 90\%) siswa. Setelah dilakukan tindakan yang disepakati yaitu dengan menerapkan strategi Card Sort pada pemebelajaran diperoleh hasil yaitu siklus I meningkat menjadi 20 (55, 60\%) siswa. Setelah dilakukan tindakan yang direvisi pada siklus II diperoleh hasil untuk jumlah siswa yang aktif bertanya dan berpendapat serta menjawab pertanyaan meningkat menjadi 29 (80, 60\%) siswa.

Selama proses pembelajaran berlangsung, kualitas pembelajaran pada tiap siklusnya mengalami peningkatan secara bertahap dan pada akhirnya dapat me-ningkatkan keaktifan bertanya dan berpendapat serta menjawab pertanyaan. Pada siklus I, belum didapatkan hasil yang memuaskan. Hal ini disebabkan keadaan siswa yang masih belum mengerti maksud dan tujuan 
apa yang mereka lakukan. Siswa masih asing dengan pembelajaran dengan strategi Cart Sort. Pembelajaran tindakan kelas siklus II berjalan lebih baik jika dibandingkan dengan tindakan siklus I. Hasil yang dicapai juga meningkat, hal ini karena siswa sudah mengetahui tahap-tahap dalam strategi pembelajaran dengan strategi Card Sort. Gambar berikut adalah grafik perkembangan penerapan strategi Card Sort dalam upaya meningkatkan keaktifan siswa mulai dari kondisi awal sampai pada tindakan II.

Gambar 2. Peningkatan keaktifan siswa kelas VII SMP Negeri 4 Satu Atap Gabus Secara Keseluruhan

\begin{tabular}{|c|c|}
\hline & Peningkatan Keaktifan Siswa \\
\hline Awal & Seaktifan \\
Siswa \\
Kondisi
\end{tabular}

\section{Keterangan:}

1. Keaktifan siswa pada kondisi awal sebanyak 5 (13,90\%) siswa.

2. Keaktifan siswa pada siklus I sebanyak $20(55,60 \%)$ siswa.

3. Keaktifan siswa pada siklus II sebanyak $29(80,60)$ siswa.

\section{Kesimpulan}

Dari rangkaian putaran penelitian tindakan kelas yang telah dilakukan terlihat adanya perubahan yang merupakan hasil penelitian dalam rangka usaha meningkatkan keaktifan siswa dalam bertanya dan berpendapat serta menjawab pertanyaan pada materi HAM. Bertitik tolak dari tindakan yang telah dilaksanakan pada penelitian ini, maka dapat diambil beberapa kesimpulan sebagai berikut:

1. Penerapan strategi Card Sort telah mampu meningkatkan keaktifan bertanya dan berpendapat serta menjawab pertanyaan pada materi HAM hingga sebanyak 29 (80, 60\%) siswa. 
Peningkatan keaktifan bertanya dan berpendapat serta menjawab pertanyaan diamati melalui kegiatan diskusi kelas.

2. Kemampuan siswa dalam bertanya dan berpendapat meningkat yaitu sebelum adanya penelitian siswa yang aktif bertanya dan serta berpendapat sebanyak 5 siswa atau 13,90\%. Pada putaran I sebanyak 20 atau 55, 60\% siswa, pada putaran II sebanyak 29 atau 80, 60\% siswa.

\section{Daftar Pustaka}

Arikunto, Suharsimi. 2000. Prosedur penelitian, suatu pendekatan praktik edisi refisi V. Jakarta: Rineka Cipta.

Arikunto, Suharsimi. 2006. Penelitian Tindakan Kelas. Jakarta: Bumi Aksara.

Astuti, Fitri. 2007. Usaha Meningkatkan Keaktifan Siswa dengan Merespon Pelajaran Melalui Pendekatan Ketrampilan Proses (PKP) (PTK Pembelajaran Metematika di kelas VII SMP Negari 2 Ngemplak) Skripsi S-1. Surakarta: FKIP UMS.

Fitriasari, Dini. 2007. Upaya Meningkatkan Keaktifan Belajar Siswa dalam Pem-belajaran Matematika dengan Pendelatan Pola Latihan Interaktif Pokok Bahasa Geometri (PTK SMP Negeri 1 Pekalongan) Skripsi S-1. Surakarta: FKIP UMS.

Hasibuan, J. J. dan Moedjiono. 1995. Proses Belajar Mengajar. Bandung: PT Remaja Rosdakarya.

Miles, B. Mathew dan Michael Huberman. 1992. Analisis Data Kualitatif (Buku Sumber tentang Metode-metode Baru). Jakarta: UIP.

Nawawi, Hadari dan M. Martini. 1992. Instrumen Penelitian Bidang Sosial. Yogyakarta: Gadjah Mada University Press.

Pusat Bahasa Departemen Pendidikan Nasional. 2005. Kamus Besar Bahasa Indonesia Edisi Ketiga. Jakarta: Balai Pustaka.

TIM Abdi Guru. 2006. Pendidikan Kewarganegaraan untuk SMP Kelas VII. Jakarta: Erlangga.

TIM Penyusun Kamus Pembinaan dan Pengembangan Bahasa Depdikbut. 1991. Kamus Besar Bahasa Indonesia. Jakarata: Balai Pustaka.

Zaini, dkk. 2002. Strategi Pembelajaran Aktif Diperguruan Tinggi. Yogyakarta: CTSD (Center For Teching Staff Development). 